\title{
Reduced Ingestion of Sweetened Milk Induced by Interleukin-1 and Lipopolysaccharide Is Associated with Induction of Cyclooxygenase-2 in Brain Endothelia
}

\author{
Adrian J. Dunn ${ }^{a}$ Artur H. Swiergiel ${ }^{a}$ Hao Zhang $^{b}$ Ning Quan ${ }^{b}$ \\ a Department of Pharmacology, Toxicology and Neuroscience, Louisiana State University Health Sciences Center, \\ Shreveport, La., and ${ }^{b}$ Department of Oral Biology, Ohio State University, Columbus, Ohio, USA
}

\section{Key Words}

Behavior $\cdot$ Corticosterone $\cdot$ Cyclooxygenase2 $\cdot$ Endothelia $\cdot$

Feeding $\cdot$ Interleukin- $1 \cdot$ Lipopolysaccharide

\begin{abstract}
Previous studies have shown that interleukin-1 (IL-1) and lipopolysaccharide (LPS) administration to animals induces behavioral changes, including a reduction in feeding. These effects of IL-1 and LPS have been shown to be sensitive to inhibitors of cyclooxygenase (COX). Objectives: To determine the relationships between induction of COX-2 in the brain with IL-1 $\beta$ - and LPS-induced changes in body temperature, plasma corticosterone and feeding. Methods: Mice were injected with intraperitoneal doses of IL-1 $\beta$ and LPS that decreased feeding. The induction of COX-2 was studied immunocytochemically in the brain, in parallel with core body temperature, the drinking of sweetened milk, and plasma concentrations of corticosterone. Results: COX-2 immunoreactivity (ir) was sparse in the brains of the untreated mice, but IL-1 $\beta$ and LPS both increased its expression. This COX-2 induction appeared to be confined to blood vessels, and was not markedly region specific. Induction was evident 30 min after IL-1 or LPS, and was greater at 90 than at $30 \mathrm{~min}$. COX-2-ir in the parenchyma did not change significantly. Thus induction of COX-2 occurred in brain endothelia in par-
\end{abstract}

allel with the reduction in feeding. This is consistent with the previously determined sensitivity of IL-1-induced changes in feeding to selective COX-2 inhibitors, and the responses to IL-1 in COX-2-deficient mice. The time courses of the IL-1- and LPS-induced increases in plasma corticosterone paralleled those in the reduction in milk drinking, however, the changes in body temperature appeared later. Conclusions: Endothelial COX-2 may be involved in IL-1- and LPS-induced decreases in milk drinking, and possibly in the HPA axis activation. The decreased milk drinking may occur when IL-1 and LPS bind to receptors on brain endothelial cells subsequently inducing COX-2 and the production of prostanoids which elicit the reductions in milk drinking. Thus the behavioral effects of peripherally administered IL-1 and LPS appear to be mediated by multiple mechanisms, including endothelial COX-2, and vagal afferents.

Copyright $\odot 2006$ S. Karger AG, Basel

\section{Introduction}

Numerous previous studies have shown that interleukin-1 (IL-1) and lipopolysaccharide (LPS) administration to rats and mice induces behavioral responses collectively known as sickness behavior $[1,2]$. We have exploited the propensity of mice to drink sweetened milk to deter-

\section{KARGER}

Fax +4161306 1234 E-Mail karger@karger.ch www.karger.com
(C) 2006 S. Karger AG, Basel

$1021-7401 / 06 / 0132-0096 \$ 23.50 / 0$

Accessible online at:

www.karger.com/nim
Adrian J. Dunn, PhD

Department of Pharmacology, Toxicology and Neuroscience

Louisiana State University Health Sciences Center, PO Box 33932

Shreveport, LA 71130-3932 (USA)

Tel. +1 318675 7856, Fax +1 318675 7857, E-Mail adunn@lsuhsc.edu 
mine the mechanisms involved in the reduction in feeding. When presented with sweetened milk for 10-30 min each day, mice typically ingest 2-3 g [3]. Intraperitoneal administration of low doses of IL-1 $\beta(50-500 \mathrm{ng})$ inhibits the drinking of sweetened milk for around $3 \mathrm{~h}$. Intraperitoneal administration of low doses of LPS $(1-5 \mu \mathrm{g})$ inhibit the milk drinking for somewhat longer. These responses to IL-1 and LPS are sensitive to inhibitors of cyclooxygenase (COX) enzymes [3-5]. Interestingly, more recent studies have indicated that both COX isozymes, the constitutive COX-1 and the inducible COX-2, appear to be involved [6]. The reduction in milk intake induced by IL-1 $\beta$ in COX-2-knockout mice resembled that in wild-type mice until about $90 \mathrm{~min}$ after IL-1. At later times, no reduction in milk drinking was observed. However, COX-1-knockout mice showed no response to IL-1 $\beta$ for more than $1 \mathrm{~h}$, but subsequently the normal reduction in milk drinking occurred. Complementary studies with selective COX inhibitors indicated that the selective COX-1-inhibitor, SC560, prevented the effects of IL-1 $\beta$ only in the first hour, whereas the COX-2-selective inhibitor, celecoxib, was effective only at later times [6]. Celecoxib also inhibited the response to LPS [7]. These results suggested that COX-1 was primarily responsible for the early decrease in milk drinking, whereas COX-2 was responsible for the later phase.

These studies provided no information on the location of the COX enzymes involved. Therefore, we have now studied the induction of COX-2 in the brains of mice treated with intraperitoneal doses of IL- $1 \beta$ and LPS using immunohistochemistry. We also monitored the changes in plasma corticosterone in the same animals. The results confirm that both IL-1 $\beta$ and LPS at physiologically and behaviorally active doses increase the expression of COX2 in brain endothelia, and that the time course of this response parallels the appearance of the COX-2-sensitive decrease in milk drinking.

\section{Materials and Methods}

\section{Animals}

Separate batches of CD-1 albino, VF male mice were obtained from Charles River (R16 colony Raleigh-Durham facility) and upon arrival housed in an animal colony room maintained at $22 \pm 2{ }^{\circ} \mathrm{C}$ and with 12-hour light-dark cycle with lights on at 7 AM. They were kept in plastic cages with wood shavings as bedding in groups of 5 for at least 1 week and were then placed in individual cages. Mice were given free access to water and Purina chow pellets. The animals were 4-7 weeks old and weighed between 30 and $40 \mathrm{~g}$ at the beginning of the experiments. All experiments were conducted between $8 \mathrm{AM}$ and $1 \mathrm{PM}$ and in accor- dance with the NIH Guide on the care and use of animals for research, and an in-house protocol approved by the Louisiana State University Health Sciences Center-Shreveport Animal Care and Use Committee.

\section{Materials}

Recombinant mouse IL-1 $\beta$ (mIL-1 $\beta$ ) was purchased from R\&D Systems (Minneapolis, Minn., USA) and Escherichia coli LPS was from Sigma (St. Louis, Mo., USA; LPS; L3755, serotype 026:B6). mIL-1 $\beta$ (100 ng/mouse) and LPS ( $1 \mu \mathrm{g} /$ mouse) were dissolved in a sterile pyrogen-free $0.9 \%$ solution of sodium chloride such that the total dose for each mouse was contained in $0.1 \mathrm{ml}$ which was injected intraperitoneally. Control animals were injected with sterile saline. COX-2 goat anti-mouse antibody was obtained from Santa Cruz Biotechnology, Santa Cruz, Calif., USA.

\section{Milk Intake}

Short-term milk drinking was assessed in non-fasted mice at the beginning of the light phase. Intake of sweetened condensed milk diluted with three parts of water was assessed as described previously [3]. Briefly, mice were habituated for at least 3 days to drink milk from 20 -ml glass bottles fitted with metal spouts. The weighed bottles were placed in the cages for $10 \mathrm{~min}$, then removed and reweighed. On the experimental day, sweetened milk was presented immediately, and 15, 30, 60, 90, 120, 180, and $240 \mathrm{~min}$ after injection of IL-1 $\beta$ or LPS. In the animal room, each mouse was removed from its cage, according to a time schedule, gently weighed, given an intraperitoneal injection of saline, IL-1 $1 \beta$ or LPS, and returned to its home cage. Thus, the injections were given at different times and all animals in the room were given milk at the same time.

\section{Measurement of Core Body Temperature}

Mice were anesthetized using Innovar Plus (3 mg fentanyl, $210 \mathrm{mg}$ droperidol and $150 \mathrm{mg}$ midazolam dissolved in $174 \mathrm{ml}$ of water) at a dose of $10 \mu \mathrm{l} / \mathrm{g}$ body weight intraperitoneally. The mouse was placed on its back, a short incision (1 cm long) was made in its abdomen and a telethermometer (Minimitter model VM-FHA, MiniMitter, Bend, Oreg., USA) was placed into its abdominal cavity. The Minimitters were coated using paraffin/ Elvax $^{\circledR}$ from El Du Pont de Nemours (Wilmington, Del., USA), and disinfected with Zephiran chloride (1:1,000). The abdominal muscles and the skin were then sutured with surgical silk and topical antibiotic (Neosporin) applied to counter infection. The colony room was maintained at an ambient temperature of $22 \pm$ $2{ }^{\circ} \mathrm{C}$. Body temperature was monitored remotely, without touching or disturbing the animals, every $20 \mathrm{~min}$ for $1 \mathrm{~h}$ before IL-1 and LPS injection, and for $10 \mathrm{~h}$ afterwards.

\section{Immunohistochemistry}

Mice were perfused with paraformaldehyde 30 or 90 min after injection of saline, mIL-1 $\beta$ or LPS. 'Quiet' animals did not receive any injections and were sacrificed immediately after removing them from their home cages. For the immunohistochemical studies, mice were overdosed with pentobarbital (65 mg/kg, i.p.). Five minutes later they were perfused with gravity fed saline (bottles $100 \mathrm{~cm}$ above the animal) followed by $4 \%$ freshly prepared paraformaldehyde. The thoracic cavity was opened and a blunt needle inserted into the left ventricle. The inferior vena cava was cut, and about $100 \mu$ l of blood withdrawn into a syringe (for determination 
of plasma corticosterone) and the saline allowed to flow through the mouse. After about $15 \mathrm{~min}$, a valve was switched so that paraformaldehyde flowed through the carcass for $15 \mathrm{~min}$. The brains were removed, and postfixed in $4 \%$ paraformaldehyde for $4 \mathrm{~h}$. They were then transferred to a $30 \%$ sucrose solution and stored at $4{ }^{\circ} \mathrm{C}$ overnight. The brains were then frozen at $-80^{\circ} \mathrm{C}$ and later cut into $10-\mu \mathrm{m}$ sections on a cryostat.

Brain sections were air-dried and fixed in a mixture containing $75 \%$ acetone and $25 \%$ alcohol for $5 \mathrm{~min}$. Glucose oxidase and sodium azide were used to reduce background interference. Sections were then incubated with goat anti-COX-2 (1:200, Santa Cruz Biotechnology) overnight at $4^{\circ} \mathrm{C}$. The primary antibody was detected by incubation with a biotinylated secondary antibody (donkey anti-goat, 1:200). Staining was then visualized with the conventional avidin-biotin immunoperoxidase method [8]. A pilot study and three separate experiments were performed with similar results.

\section{Quantification of COX-2-Labeled Blood Vessels}

To quantify COX-2 staining, coronal sections at the level of bregma $+0.38 \mathrm{~mm}$ were examined. Matching sections from different animals were collected at the exact same coronal level of the brain. This was verified by staining an adjacent section. The number of stained blood vessels was counted in a rectangular area in the cortex (ventral: from 1 to $2 \mathrm{~mm}$, and lateral: from -0.8 to $0.8 \mathrm{~mm}$ ), and in a rectangular area of the hypothalamus including the ventral medial preoptic area (ventral: from 4.8 to $5.8 \mathrm{~mm}$, and lateral: from -0.8 to $0.8 \mathrm{~mm}$ ). The coordinates were determined according to the mouse brain atlas of Franklin and Paxinos [9].

\section{Corticosterone Assay}

Blood was collected in 1.5-ml Eppendorf tubes containing EDTA and centrifuged, and plasma corticosterone concentration was determined in duplicate using a radioimmunoassay (ICN Biomedicals, Costa Mesa, Calif., USA) as described by the manufacturer.

\section{Statistical Analysis}

Data were analyzed with two-way analysis of variance (ANOVA). Treatment and time were the main factors. Pairwise comparisons were performed using the least significant difference test. Results are reported as means \pm SEM.

\section{Results}

\section{Effects of IL-1 $\beta$ and LPS on Milk Intake}

In individually housed animals, intraperitoneal administration of mIL-1 $\beta$ (fig. 1) or LPS (fig. 2) decreased the 10 -min milk intake in non-fasted mice. IL-1 $\beta$ depressed milk intake as early 15 min after its administration. This effect of IL- $1 \beta$ lasted for at least $120 \mathrm{~min}$, but $180 \mathrm{~min}$ after the injection it was no longer statistically significant. ANOVA revealed statistically significant effects of IL-1 $\left(\mathrm{F}_{1,109}=136, \mathrm{p}<0.001\right)$, time $\left(\mathrm{F}_{7,109}=6.95\right.$, $\mathrm{p}<0.001)$, and a significant treatment $\times$ time interaction $\left(\mathrm{F}_{7,109}=5.34, \mathrm{p}<0.001\right)$.
LPS began to depress drinking about $30 \mathrm{~min}$ after its administration (fig. 2). The nadir occurred at about $2 \mathrm{~h}$, and there was some recovery by the 4 th $\mathrm{h}$. ANOVA revealed statistically significant effects of LPS $\left(\mathrm{F}_{1,81}=31\right.$, $\mathrm{p}<0.001)$, time $\left(\mathrm{F}_{7,81}=4.94, \mathrm{p}<0.001\right)$, and a significant treatment $\times$ time interaction $\left(\mathrm{F}_{7,81}=4.92, \mathrm{p}<0.001\right)$.

In many previous experiments, both IL-1 $\beta$ and LPS treatments caused slight reductions in body weight measured the following day. In the experiment of figure 1 , IL- $1 \beta$ resulted in a mean loss of $0.4 \mathrm{~g}$, that did not attain statistical significance. LPS induced a slightly larger decrease $(1.1 \mathrm{~g})$ that was statistically significant $(\mathrm{t}=3.21$, $\mathrm{p}<0.01)$.

\section{Effects of IL-1 $\beta$ and LPS on Body Temperature}

Core body temperature was measured using telemetry in freely moving and undisturbed mice. The changes following intraperitoneal administration of IL- $1 \beta$ and LPS are presented in figure 3. In comparison with saline, IL$1 \beta$ induced an initial decrease in body temperature for the first $2 \mathrm{~h}$ after IL-1 $\left(\mathrm{F}_{1,72}=20, \mathrm{p}<0.001\right)$ followed by an increase in the following $2.5 \mathrm{~h}\left(\mathrm{~F}_{1,40}=27, \mathrm{p}<0.001\right)$. Across the entire experiment (temperature measurements at 21 time points), there was a significant treatment $\times$ time interaction $\left(\mathrm{F}_{20,168}=2.48, \mathrm{p}<0.001\right)$.

LPS also induced significant increases in body temperature in the $2 \mathrm{nd} \mathrm{h}$ after the injection. The effect was time dependent $\left(\mathrm{F}_{1,20}=8.23, \mathrm{p}<0.001\right)$ and dissipated by $6 \mathrm{~h}$ after LPS. ANOVA indicated statistically significant effects of LPS $\left(\mathrm{F}_{1,210}=49, \mathrm{p}<0.001\right)$, and a significant treatment $\times$ time interaction $\left(\mathrm{F}_{20,210}=2.20, \mathrm{p}<0.01\right)$. The initial rise in temperature observed in both groups in this experiment appeared to be associated with the stress of injection. In our experiments, such an effect appears to be associated with the initial body temperature of the mice, and is not specifically associated with IL-1 $\beta$ or LPS treatments.

\section{Effects of IL-1 $\beta$ and LPS on Plasma Corticosterone}

Administration of mIL- $1 \beta$ increased the concentrations of corticosterone in blood plasma at 30 and $90 \mathrm{~min}$ (fig. 4). The effect of IL-1 $\beta$ was statistically significant $\left(\mathrm{F}_{1,25}=143, \mathrm{p}<0.001\right)$ and increased with time (IL-1 $\times$ time interaction: $\left.\mathrm{F}_{1,25}=16.0, \mathrm{p}<0.001\right)$. When LPS was injected, the results were similar, although this response appeared somewhat more slowly than that to IL-1 $\beta$, such that the increase in plasma corticosterone was statistically significant only at 90 min (LPS: $\mathrm{F}_{1,25}=19.1, \mathrm{p}<$ 0.001; time $\times$ LPS interaction: $\left.F_{1,25}=5.69, p<0.05\right)$. 


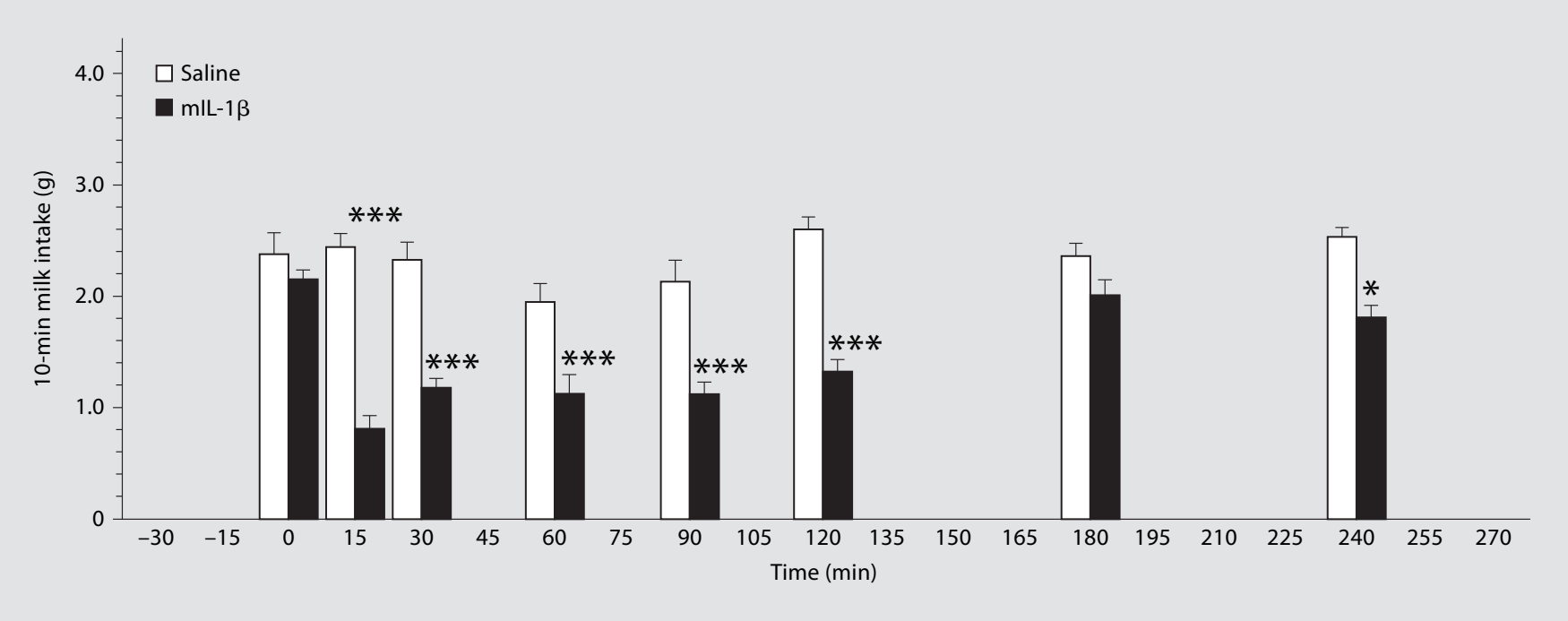

1

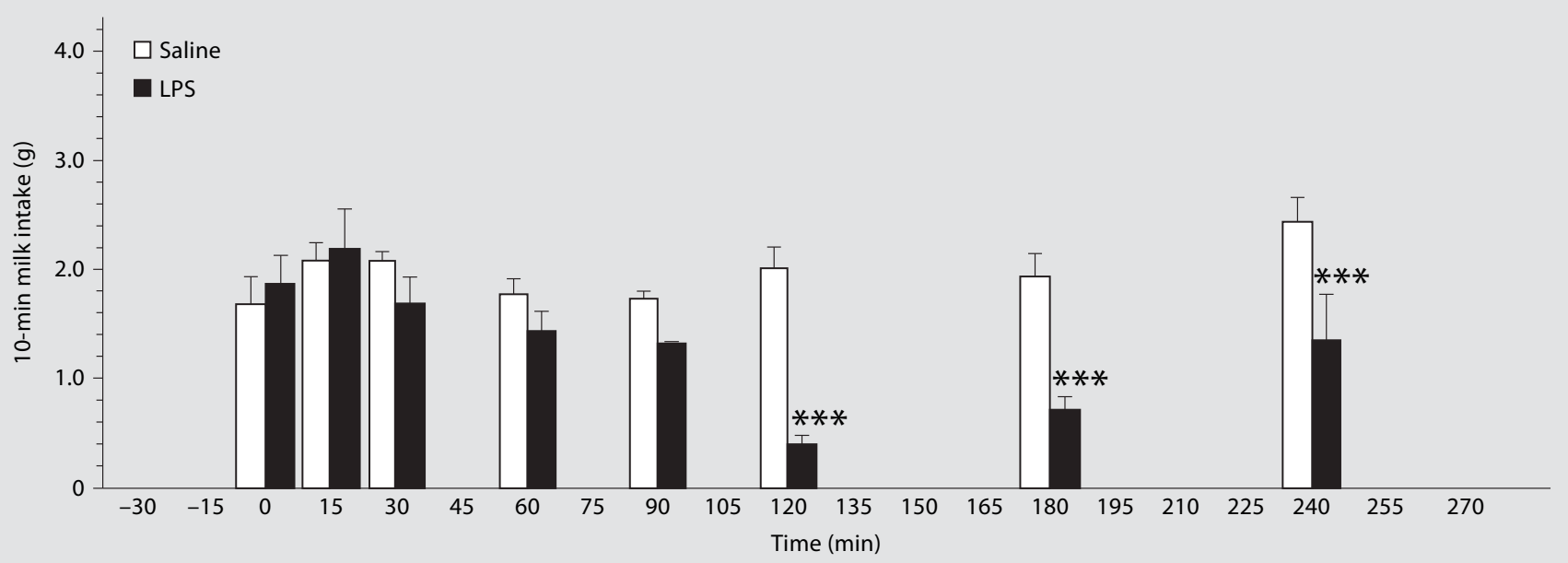

2

Fig. 1, 2. Time course of the effects of IL-1 $\beta$ (1) and LPS (2) on milk intake. Mice were injected with saline, mIL$1 \beta$ (100 ng, i.p.; 1) or LPS (1 $\mu$ g i.p.; 2) and milk bottles placed in the cages for $10 \mathrm{~min}$ (immediately, and 15, 30, $60,90,120,180$, and $240 \mathrm{~min}$ after the injection). ${ }^{*} \mathrm{p}<0.05,{ }^{* * *} \mathrm{p}<0.001$, vs. the saline-injected group. $\mathrm{n}=8$ (1) and 4-6 (2) per time point.

Effects of IL-1 $\beta$ and LPS on the Expression of COX-2

A low expression of COX-2 was observed in the quiet and saline-injected animals (fig. 5a, b). Limited constitutive expression of COX-2 was observed in neurons, as reported previously (data not shown). COX-2 was induced in the blood vessels of the hypothalamus after either IL$1 \beta$ or LPS injection (fig. $5 c-f$ ). A similar COX-2 induction was observed in the blood vessels of the cortex (data not shown).

Quantitative analysis showed that significant increases in COX-2ir in blood vessels occurred 30 and $90 \mathrm{~min}$ after either IL-1 $\beta$ or LPS injection. The strongest induction was seen 90 min after IL-1 $\beta$ or LPS. In the cortex (fig. 6a), the effect of IL-1 was statistically significant 30 and 90 min after injection $\left(\mathrm{F}_{1,23}=71, \mathrm{p}<0.001\right)$. A statistically significant interaction between IL-1 $\beta$ and time $\left(\mathrm{F}_{1,23}=5.69, \mathrm{p}<0.05\right)$ was also observed. LPS also induced a significant increase in the number of COX-2-positive blood vessels at $90 \mathrm{~min}$, but not $30 \mathrm{~min}$ after injection $\left(\mathrm{F}_{1,19}=21.7, \mathrm{p}<0.001\right)$. The interaction between LPS and time did not reach statistical significance $\left(\mathrm{F}_{1,19}=\right.$ 3.14). In the hypothalamus (fig. 6b), administration of 
Fig. 3. Time course of the effects of IL-1/3 and LPS on body temperature of mice with implanted radiotelethermometers (MiniMitters). Mice were injected with saline or IL-1/3 (100 ng i.p.; a) or LPS (1 $\mu$ g i.p.; b) and temperature was recorded at 30 -min intervals for 8 h. ${ }^{*} \mathrm{p}<0.05$ vs. saline. $\mathrm{n}=6$.

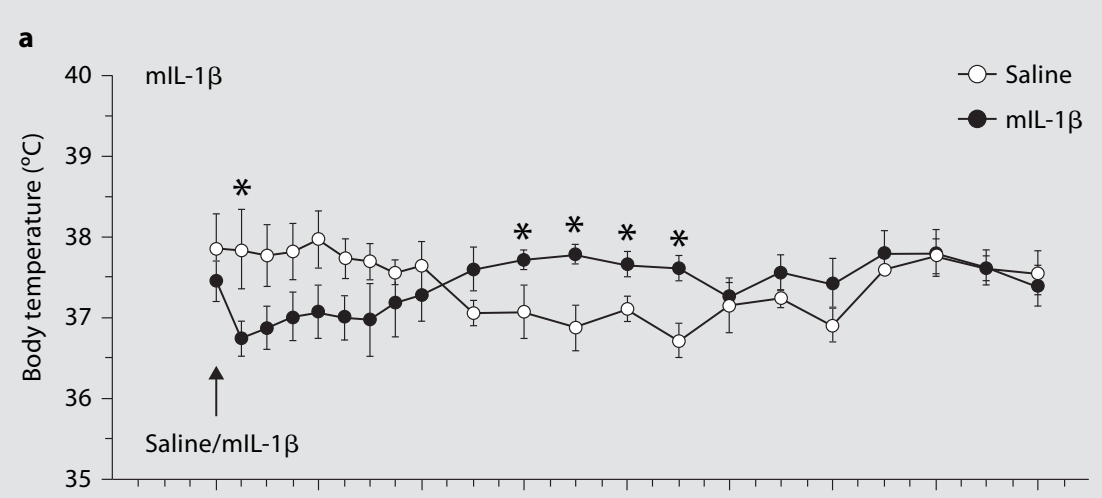

b

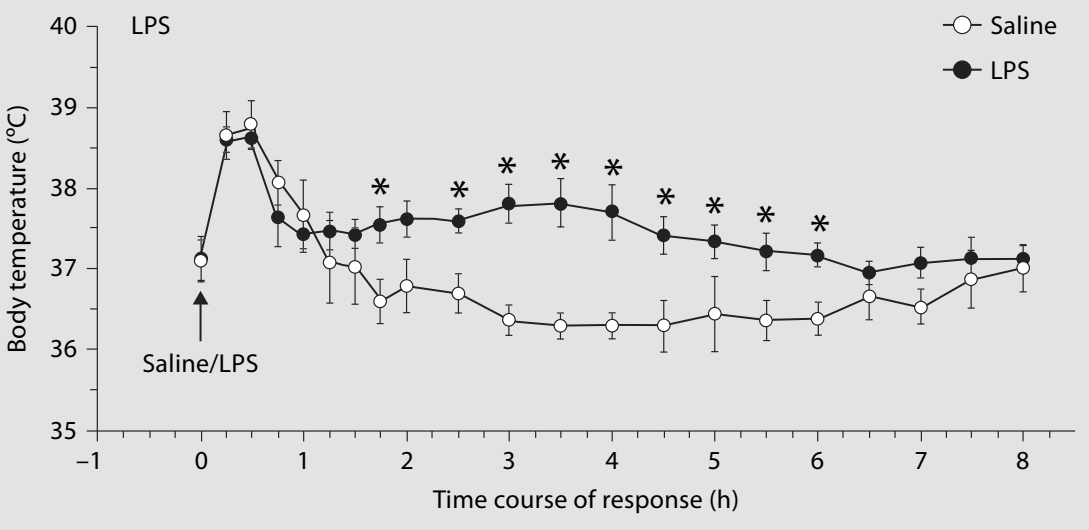

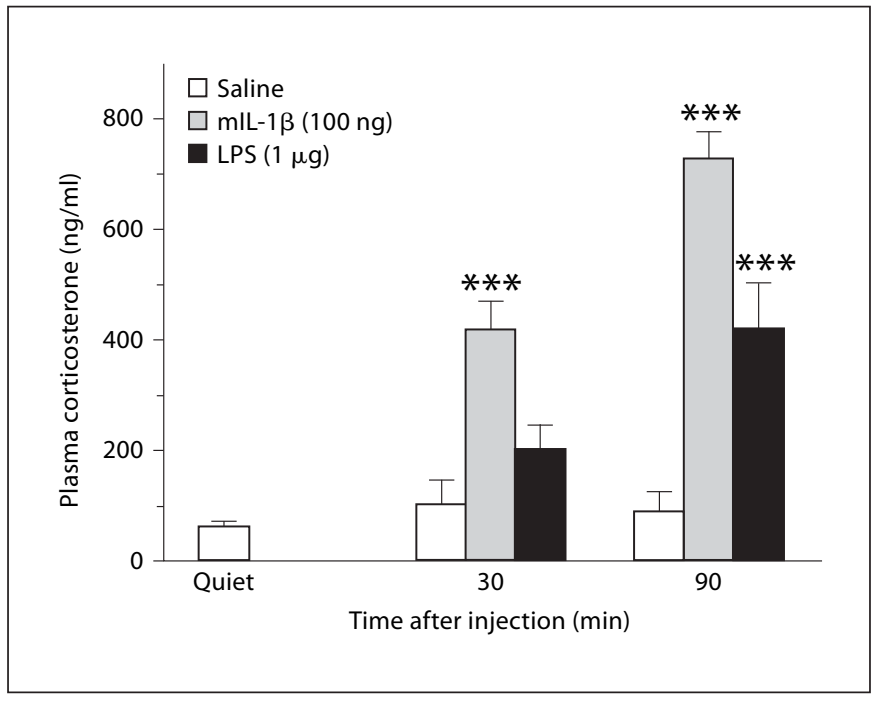

Fig. 4. The effects of IL-1 $\beta$ and LPS on plasma corticosterone. Mice were uninjected (quiet) or were injected with saline, mIL-1 $\beta$ (100 ng i.p.) or LPS (1 $\mu$ g i.p.) and blood plasma was collected 30 or 90 min after the injections $(n=6){ }^{* * *} \mathrm{p}<0.001$ vs. saline.
IL-1 significantly increased COX-2 expression $\left(\mathrm{F}_{1,23}=37\right.$, $\mathrm{p}<0.001) 30$ and $90 \mathrm{~min}$ after injection. There was a significant interaction between IL- $1 \beta$ and time $\left(F_{1,23}=5.15\right.$, $\mathrm{p}<0.05)$. LPS significantly increased the number of COX-2-positive blood vessels at $90 \mathrm{~min}$, but not at $30 \mathrm{~min}$ after the injection $\left(\mathrm{F}_{1,21}=22.2, \mathrm{p}<0.001\right)$. There was a significant interaction between LPS and time $\left(\mathrm{F}_{1,21}=\right.$ $6.66, \mathrm{p}<0.001)$.

\section{Discussion}

The present results show that intraperitoneal injection of IL- $1 \beta$ or LPS induces COX-2 in blood vessels in the mouse brain. This was evident in the immunocytochemical images of the brain tissue treated with antibody selective for COX-2 (fig. 5), and in the quantitative data for both hypothalamus and cortex (fig. 6). The induction of COX-2 was not markedly regionally selective. However, COX-2 induction appeared to be confined to cells in the 

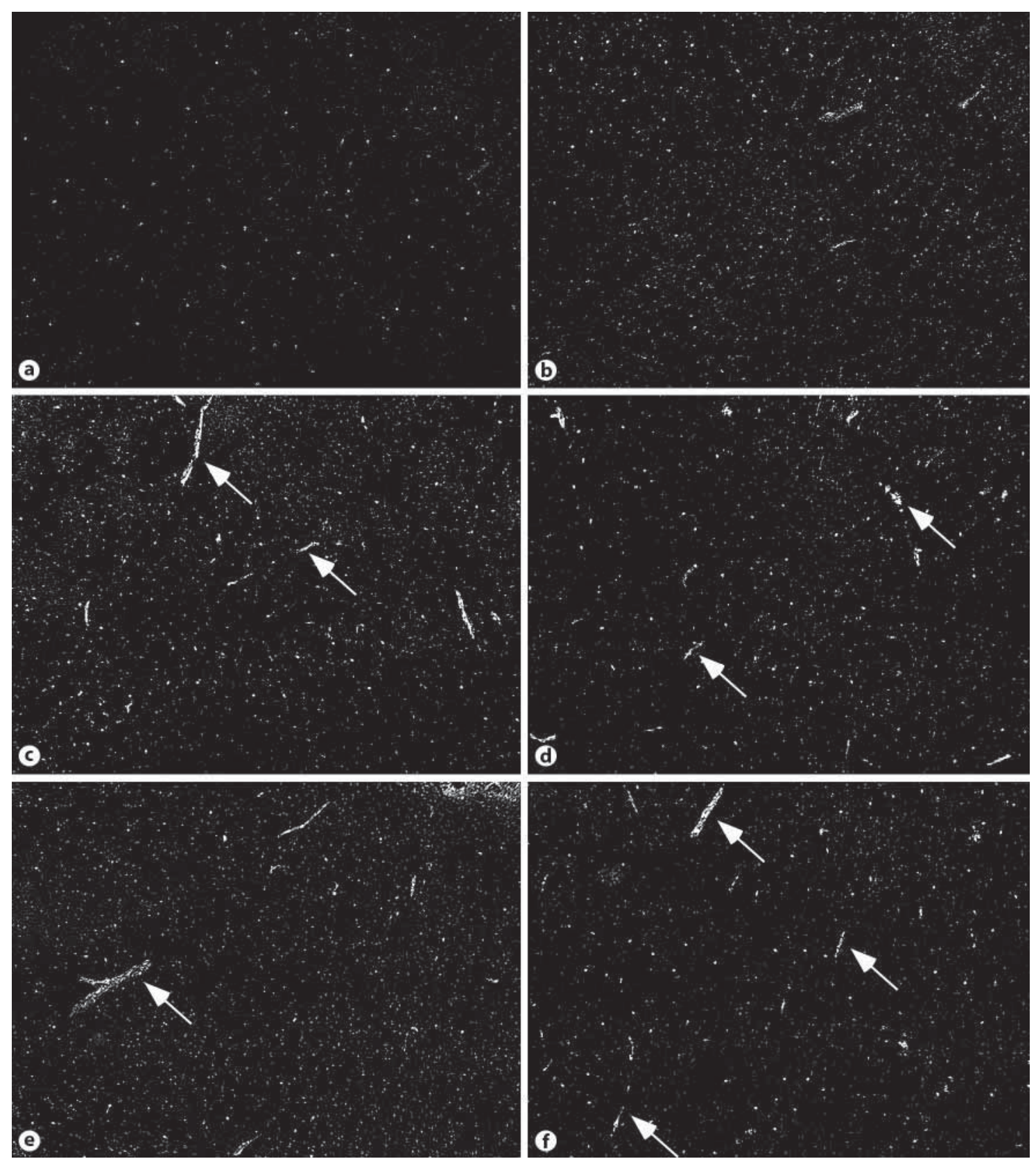

Fig. 5. Representative microphotographs showing COX-2ir in the brain. The pictures were taken from sections containing the ventromedial preoptic area. Low expression of COX-2 was seen in the brains of quiet (a) and saline-injected mice (b). More labeled blood vessels were seen 30 min after either IL-1 $\beta$ (c) or LPS (d) injection. Significant expression of COX-2 in blood vessels was seen 90 min after IL-1 (e) or LPS injection (f). Arrows indicate labeled blood vessels.

blood vessels, because no changes were detected in the limited expression of COX-ir in the brain parenchyma. Saline-treated animals showed a small increase in COX2ir relative to quiet animals, but this effect was not statis- tically significant (fig. 6). The effects of IL-1 $\beta$ were statistically significant 30 and 90 min after intraperitoneal administration, whereas the responses to LPS were statistically significant only at $90 \mathrm{~min}$. This induction of 


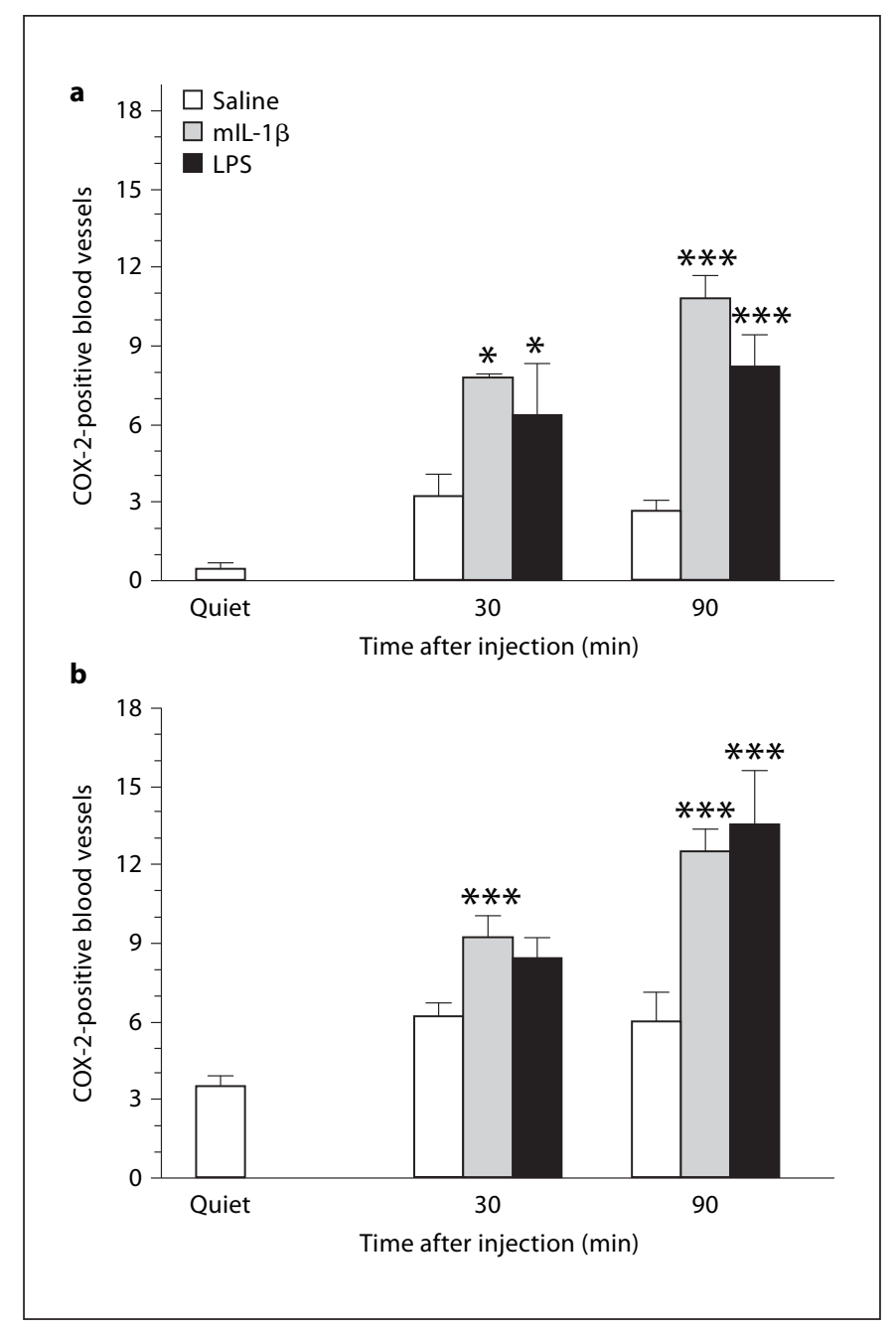

Fig. 6. Quantitative analysis of the number of labeled blood vessels in cortex and hypothalamus from the experiment depicted in figures 4 and 5 . Stained blood vessels on matching coronal brain sections were counted. The anterior-posterior coordinate of the sections was bregma $+0.38 \mathrm{~mm}$. The number of stained blood vessels was counted in a rectangular area of the cortex (ventral: from 1 to $2 \mathrm{~mm}$; lateral: from -0.8 to $0.8 \mathrm{~mm}$ ), and in a rectangular area of the hypothalamus including the ventral medial preoptic area (ventral: from 4.8 to $5.8 \mathrm{~mm}$, lateral: from -0.8 to $0.8 \mathrm{~mm}$ ). a Data from the cortex. $\mathbf{b}$ Data from the hypothalamus from the experiment shown in figure $5 .{ }^{*} \mathrm{p}<0.05$, ${ }^{* *} \mathrm{p}<0.001$, vs. saline.

COX-2 in the brain blood vessels by IL- $1 \beta$ and LPS is consistent with previous results [10-14], and has been shown to occur primarily in perivascular cells [14]. The present results indicate that the induction of COX-2 occurs with the same time course as the reduction in sweetened milk intake and the increase in plasma corticosterone ob- served with injections of the same doses of IL-1 $\beta$ and LPS (fig 1, 2, 4).

In previous studies, we obtained evidence that both COX-1 and COX-2 are involved in the reduction in sweetened milk intake induced by IL-1 $\beta$ [6]. In those studies, SC560, a selective inhibitor of COX-1, inhibited the early (i.e. 30-min) response to IL-1 $\beta$, but not after $1 \mathrm{~h}$. Moreover, the selective COX-2 inhibitor, celecoxib, had no effect at $30 \mathrm{~min}$, but inhibited milk ingestion at $90 \mathrm{~min}$. Furthermore, COX-1-knockout mice failed to show any early response to IL-1 $\beta$, whereas the response was like that in wild-type mice at $90 \mathrm{~min}$. Conversely, COX-2knockout mice showed a normal response to IL-1 $\beta$ at $30 \mathrm{~min}$, but there was no response at $90 \mathrm{~min}$ [6]. We interpreted these findings to indicate that the constitutive COX-1 was responsible for the response to IL- $1 \beta$ in the 1 st $\mathrm{h}$ or so, whereas COX-2 was involved at later times. Why COX-1 was no longer involved at the later times is not known. The present results suggest that the appearance of the COX-2-sensitive behavioral responses to IL$1 \beta$ accompanies the induction of COX-2 in endothelial cells.

The effects of IL- $1 \beta$ and LPS on COX-2 and milk intake were paralleled by increases in plasma corticosterone (fig. 4), although the effect of LPS was not statistically significant at $30 \mathrm{~min}$, consistent with our earlier data that it takes LPS longer to stimulate the HPA axis [15, 16]. Thus induction of endothelial COX-2 may also be involved in the HPA responses to IL-1 $\beta$ and LPS.

In comparison with the behavioral and HPA responses, the fever associated with IL-1 $\beta$ and LPS administration was not clearly apparent until 2-3 h after IL-1 and LPS and was not closely related to the COX-2 induction (fig. 3). However, this does not preclude a role for COX-2 in the changes in core body temperature. In fact, Li et al. [17] showed that COX-2-knockout mice failed to show the late phase of the fever in response to LPS, implicating COX-2. The delay in the fever may be related to the mechanisms involved in generating this late phase of the fever.

Because LPS induces the secretion of IL- $1 \beta$ from macrophages and various other cell types [18], it is possible that the effects of LPS are induced by IL- $1 \beta$ production. However, IL-1 $\beta$ does not appear until around $60 \mathrm{~min}$ after LPS [18], whereas the reduction in milk intake and the induction of COX-2 occurs earlier. Laflamme et al. [19] studied the potential role of IL-1 in the LPS-induced induction of COX-2 in brain endothelia, but observed that although IL-1 and LPS both induced endothelial COX-2, the response to LPS in IL-1 $\beta$-knockout mice was similar 
to that of wild-type animals. These results are consistent with our observations that the IL-1-receptor antagonist had little effect on the LPS-induced activation of the HPA axis $[20,21]$.

An important possibility is that IL-1 $\beta$ exerts its effects on milk drinking by acting directly on the IL-1-receptors believed to be present on endothelial cells [12]. The induction of COX-2 would enable the synthesis of prostaglandin $\mathrm{H}_{2}$, which can then be converted to other prostaglandins, most probably prostaglandin $\mathrm{E}_{2}$, which may be responsible for the reduction in milk drinking. A similar mechanism may be involved in the HPA response, which follows a similar time course. This mechanism may also contribute to the febrile response.

Because blood vessels are also known to bear receptors for LPS [22], it is likely that LPS acts directly on these receptors to activate COX-2 and hence prostaglandin synthesis. Thus LPS may act directly on LPS receptors, and by inducing IL-1 which then acts on IL-1-receptors to induce the behavioral and HPA responses, and fever. This would explain the complexity of the effects of LPS on milk intake and the activation of the HPA axis.

In conclusion, the present study shows that intraperitoneal administration of IL- $1 \beta$ and LPS induces COX-2 in cerebral endothelia. The time courses of these induc- tions parallel the reductions in milk ingestion, suggesting that the induced COX-2 is involved in this response. This conclusion is complemented by data showing that selective COX-2 inhibitors inhibit the later phases of IL-1 $\beta$ and LPS-induced reductions in milk drinking, and that the effects of IL-1 $\beta$ and LPS are absent in COX-2-knockout mice [6]. Thus it is likely that direct action of IL-1 $\beta$ and LPS on cerebral blood vessels is a major mechanism for this behavioral response. However, this is probably not the only mechanism by which IL-1 $\beta$ and LPS induce hypophagia. It may complement other mechanisms involved in the responses of the brain to peripherally generated or administered IL-1, such as signaling via the vagus nerve [23-25], and the appearance of IL-1 within the brain $[1,26]$.

\section{Acknowledgments}

We thank Glenn Farrar for technical assistance. This work was supported by grants from the National Institutes of Health to A.J.D. (NS35370) and to N.Q. (NS40098). A.H.S. also has an appointment in the Department of Animal Behavior, Institute of Genetics and Animal Breeding, Polish Academy of Sciences, Jastrzebiec, Poland.

\section{References}

1 Dantzer R, Bluthé RM, Castanon N, Chauvet N, Capuron L, Goodall G, Kelley KW, Konsman JP, Layé S, Parnet P, Pousset F: Cytokine effects on behavior; in Ader R, Felten D, Cohen N (eds): Psychoneuroimmunology. San Diego, Academic Press, 2001, pp 703-727.

-2 Larson SJ, Dunn AJ: Behavioral effects of cytokines. Brain Behav Immun 2001;15:371387.

-3 Swiergiel AH, Smagin GN, Dunn AJ: Influenza virus infection of mice induces anorexia: comparison with endotoxin and interleukin-1 and the effects of indomethacin. Pharmacol Biochem Behav 1997;57:389_ 396.

4 McCarthy DO, Daun JM: The effects of cyclooxygenase inhibitors on tumor-induced anorexia in rats. Cancer 1993;71:486-492.

5 Johnson RW, Curtis SE, Dantzer R, Kelley KW: Central and peripheral prostaglandins are involved in sickness behavior in birds. Physiol Behav 1993;53:127-131.

-6 Swiergiel AH, Dunn AJ: Distinct roles for cyclooxygenases 1 and 2 in interleukin-1-induced hypophagia. J Pharmacol Exp Ther 2002;302:1031-1036.
7 Swiergiel AH, Dunn AJ: Cyclooxygenase 1 is not essential for hypophagic responses to interleukin-1 and endotoxin in mice. Pharmacol Biochem Behav 2001;69:659-663.

8 Quan N, He L, Lai W: Endothelial activation is an intermediate step for peripheral lipopolysaccharide induced activation of paraventricular nucleus. Brain Res Bull 2003;59: 447-452.

9 Franklin KBJ, Paxinos G: The Mouse Brain in Stereotaxic Coordinates. San Diego, Academic Press, 1997.

10 Cao C, Matsumura K, Yamagata K, Watanabe Y: Endothelial cells of the rat brain vasculature express cyclooxygenase-2 mRNA in response to systemic interleukin-1 1 : a possible site of prostaglandin synthesis responsible for fever. Brain Res 1996;733:263-272.

11 Cao C, Matsumura K, Ozaki M, Watanabe Y: Lipopolysaccharide injected into the cerebral ventricle evokes fever through induction of cyclooxygenase-2 in brain endothelial cells. J Neurosci 1999;19:716-725.
12 Matsumura K, Cao C, Ozaki M, Morii H, Nakadate K, Watanabe Y: Brain endothelial cells express cyclooxygenase-2 during lipopolysaccharide-induced fever: light and electron microscopic immunocytochemical studies. J Neurosci 1998;18:6279-6289.

13 Quan N, Whiteside M, Herkenham M: Cyclooxygenase 2 mRNA expression in rat brain after peripheral injection of lipopolysaccharide. Brain Res 1998;802:189-197.

14 Schiltz JC, Sawchenko PE: Distinct brain vascular cell types manifest inducible cyclooxygenase expression as a function of the strength and nature of immune insults. J Neurosci 2002;22:5606-5618.

15 Dunn AJ: Endotoxin-induced activation of cerebral catecholamine and serotonin metabolism: comparison with interleukin-1. J Pharmacol Exp Ther 1992;261:964-969.

16 Dunn AJ: Cytokine activation of the HPA axis. Ann NY Acad Sci 2000;917:608-617.

17 Li S, Wang Y, Matsumura K, Ballou LR, Morham SG, Blatteis CM: The febrile response to lipopolysaccharide is blocked in cyclooxygenase-2-/-, but not in cyclooxygenase-1-/mice. Brain Res 1999;825:86-94. 
18 Givalois L, Dornand J, Mekaouche M, Solier $\mathrm{MD}$, Bristow AF, Ixart G, Siaud P, Assenmacher I, Barbanel G: Temporal cascade of plasma level surges in ACTH, and corticosterone, and cytokines in endotoxin-challenged rats. Am J Physiol 1994;267:R164R170.

19 Laflamme N, Lacroix S, Rivest S: An essential role of interleukin-1 $\beta$ in mediating NF$\kappa \mathrm{B}$ activity and COX-2 transcription in cells of the blood-brain barrier in response to a systemic and localized inflammation but not during endotoxemia. J Neurosci 1999;19: 10923-10930
20 Dunn AJ: The role of interleukin-1 and tumor necrosis factor $\alpha$ in the neurochemical and neuroendocrine responses to endotoxin. Brain Res Bull 1992;29:807-812.

21 Dunn AJ: Effects of the interleukin-1 (IL-1) receptor antagonist on the IL-1- and endotoxin-induced activation of the HPA axis and cerebral biogenic amines in mice. Neuroimmunomodulation 2000;7:36-45.

22 Singh AK, Jiang Y: How does peripheral lipopolysaccharide induce gene expression in the brain of rats? Toxicology 2004;201:197207.

23 Watkins LR, Maier SF, Goehler LE: Cytokine-to-brain communication: a review \& analysis of alternative mechanisms. Life Sci 1995;57:1011-1026.
24 Dunn AJ: Mechanisms by which cytokines signal the brain; in Clow A, Hucklebridge F (eds): Neurobiology of the Immune System, International Review of Neurobiology. San Diego, Academic Press, 2002, vol 52, pp 4365.

25 Wieczorek M, Pournajafi-Nazarloo H, Swiergiel AH, Dunn A: Physiological and behavioral responses to interleukin-1 $\beta$ and LPS in vagotomized mice. Physiol Behav 2005;84:500-511.

26 Dantzer R: Cytokine-induced sickness behavior: where do we stand? Brain Behav Immun 2001;15:7-24. 